\title{
Molecular Characterization of Protease Producing Stenotrophomonas and Their Cytotoxic Effects on Cancer Cell Lines
}

\author{
Anamika Thakur, Sanju Kumari, Utkarshini Sharma, Rohit Krishna, Kanak Sinha and Santosh Kumar* \\ Department of Botany, B R A Bihar University, India
}

Submission: September 24, 2018; Published: October 24, 2018

*Corresponding author: Santosh Kumar, Biotechnology Unit, Department of Botany, B R A Bihar University, Muzaffarpur 842001, India; Tel: +919430457833; Fax: +91621242495; Email: skumar0112@yahoo.co.in

\begin{abstract}
Proteases are highly required where proteins need some sort of alteration either structurally or functionally. They are widely used in household laundry, paper and leather industries as well as in several pharmaceutical compounds. Thus, the present study was confined to screen more than fifty isolates of microbes from the rhizospheres of fruit orchard for proteolytic activity on skimmed milk agar medium. Isolates SK701 and SK709 were found producing halo regions around the streaked mycelia. However, only isolate SK709 displayed maximum 64.6 U/ $\mathrm{ml}$ protease activities in starch casein broth after 96 hours of culture at optimum conditions of $35^{\circ} \mathrm{C}$ and $\mathrm{pH}$ 7.6. It was identified as a gramnegative bacterium on the basis of staining, morphological, cultural, biochemical and physiological characteristics. The cytotoxic activity of cell free extracts of isolate SK709 against EAC, SiHa \& Hep G ${ }_{2}$ cell lines in terms of IC $_{50}$ was found to be 15.1, 26.3 and $35.5 \mu \mathrm{g} / \mathrm{ml}$, respectively. The $16 \mathrm{~S}$ rRNA gene sequencing, molecular characterization and the BLAST operation as per NCBI directive to construct phylogenetic tree confirmed the putative protease producing isolate SK709 to be the species of Stenotrophomonas. The difference of $2 \%$ in the gene sequence with the closest member, Stenotrophomonas sp. MCYF1(KC734883.1) which amounted to 21 out of 1022 nucleotides, made the isolate SK709 qualified for obtaining a separate NCBI accession number KF484911..
\end{abstract}

Keywords: Stenotrophomonas;Protease; Cytotoxicity; EAC; $\mathrm{SiHa}$ and $\mathrm{HepG}_{2}$ cell lines; $16 \mathrm{~S}$ rRNA gene sequencing

\section{Introduction}

Enzymes are biocatalysts obtained from plants, animals \& microorganisms. Microbes are known for rich source of natural products with biomedical properties. They are important source of bioactive compounds especially antibiotics [1] and extracellular enzymes [2]. The ongoing research on microbes has brought a technical platform for industries by way of producing industrial enzymes viz., keratinases, pectinases, xylanases, amylases, lipases, phytases, cellulases and more prominently proteolytic or proteases (caseinases and gelatinases). Microbial exploitation for the production of these protease enzymes is highly attractive for applications in fruit, detergent, pharmaceuticals, paper industries and leather [3]. Microbes producing proteases are preferred for their easy isolation, limited space requirements and optimum temperature near $30^{\circ} \mathrm{C}$ [4]. The physical factors such as temperature, $\mathrm{pH}$, incubation time, agitation, inoculums density and the availability of carbon and nitrogen source in the media also influence its production.

Proteases almost constitute $25-30 \%$ of total global enzyme sales [5]. In recent years many authors have characterized the microbial proteases as an important group of secondary metabolites for industrial purposes. Actually, the importance of proteases lies in its mode of action: it hydrolyses bonds of amino acids, either at terminal ends (exopeptidases) or in the middle of chain (endopeptidases) [6]. The other group of proteolytic enzymes, proteinases hydrolyses the secondary structure of protein. Thus, proteolytic enzymes are highly required where proteins need some sort of alteration either structurally or functionally [7], they actually destroy cell components such as lipoprotein membranes and immunoglobulins [8]. The cytotoxic study of the culture filtrate of Stenotrophomonas maltophila caused vigorous endocytosis in cancer cell lines like Vero and HeLa cells [9]. The function of proteases is largely $\mathrm{pH}$ dependent, so based on optimum $\mathrm{pH}$, proteases have been recognized as acid proteases, neutral proteases and alkaline proteases [5,6]. Alkalophilic microorganisms such as Streptomyces, Micromonospora, Stenotrophomonas etc., are prone to produce alkaline proteases into extracellular media which are widely used in biotechnological processes.With this background the present study has been aimed to screen the isolated strains of microbes from the rhizosphere of Muzaffarpur (mainly from fruit orchards) for the production and purification of proteases and its characterization with respect to 
alteration in protein configuration to assess the cytotoxic effect on cancer cell lines.

\section{Materials and Methods}

\section{Collection of soil samples}

The soil samples were collected from rhizosphere of different locations of Muzaffarpur $\left(26^{\circ} 7^{\prime} \mathrm{N} \& 85^{\circ} 25^{\prime} \mathrm{E}\right)$ district in Bihar, India. The soil samples were taken from 2-5 inches below the surface using sterilized spatula and zipped bags. The samples were kept first at $70^{\circ} \mathrm{C}$ for 15 minutes to evaporate moisture. It was then mixed thoroughly and sieved through a domestic $1.5 \mathrm{~mm}$ pore size sieve to get rid of large debris.One gram of thus obtained sieved soil sample was suspended in conical flask having $10 \mathrm{ml}$ sterile distilled water. The flask was thoroughly shaken. It was then filtered through a two layered muslin cloth. Thereafter the sample was diluted to $10^{-5}$ dilutions and stored in sterilized test tubes at $4^{\circ} \mathrm{C}$ for $24 \mathrm{~h}$.

\section{Isolation of microbes from soil samples}

Aliquots (ml) of each dilution were spread on the surface of starch agar medium (Starch-9g, L-asparagine-9g , Ammonium sulphate $-2 \mathrm{~g}$,Tris $-2 \mathrm{~g}$, Sodium chloride $-1 \mathrm{~g}$, Dipotassium sulphate $-0.5 \mathrm{~g}$, Magnesium sulphate $-0.2 \mathrm{~g}$, Calcium chloride $-0.1 \mathrm{~g}$, Trace solution - $1 \mathrm{ml}$, Potassium Dihydrogen Phosphate -0.5g, agar $-15 \mathrm{~g}$, dissolved in one litre distilled water; $\mathrm{pH}-7.0$ ) plates, supplemented with antifungal nystatin $\left(50 \mu \mathrm{g} \mathrm{ml}^{-1}\right)$ and incubated at $35 \pm 2^{\circ} \mathrm{C}$ for seven days. Plates with around 200 colonies were selected. Streaking of single colony was carried out to purify the selected colonies on the same medium. Gram staining smears were prepared and examined under the microscope to ascertain the nature of isolates.

\section{Screening of proteolytic microbes}

More than fifty isolates, purified from the soil samples were screened by streaking the mycelium on skim milk agar medium (Skimmed milk powder-100g, peptone -5g, agar-15g, dissolved in one litre Distilled water, $\mathrm{pH} 7.0$ ) andinoculated at $35 \pm 2^{\circ} \mathrm{C}$ for $5-7$ days. The culture plates showing transparent halo zone against an opaque non-hydrolysed medium indicated the protease producing strains. Proteolytic activities of the isolates were measured by diameter of clear zone around colony on skim milk agar plates and finally two isolates, SK701 and SK709 were selected for further investigation.

\section{Cultural and morphological studies of proteolytic microbes}

The colour of colony, aerial mycelium and soluble pigment of the selected isolates when grown on starch agar medium were recorded after $96 \mathrm{~h}$ of incubation. Smears of isolates were prepared for gram staining and spore chain morphology studied under a compound light microscope (Nikon, Japan) using $1000 \times$ magnification power. Colour of the substrate mycelia (reverse of the plate) was also observed along with diffusible pigments. Various biochemical and physiological tests performed for the identification of the potential isolates were indole production, methyl red, Voges Proskauer, citrate utilization, casein hydrolysis, starch hydrolysis, urea hydrolysis, gelatin hydrolysis, $\mathrm{H}_{2} \mathrm{~S}$ production, temperature tolerance, utilization of carbon and nitrogen sources and Sodium chloride resistance.

\section{Optimization for protease production in broth culture}

Optimum conditions for growth (optical densities at $540 \mathrm{~nm}$ ) and proteinase production of the selected isolates, SK701 and SK709 were carried out in starch casein broth (soluble starch: $10 \mathrm{~g}, \mathrm{~K}_{2} \mathrm{HPO}_{4}: 2 \mathrm{~g}, \mathrm{KNO}_{3}: 2 \mathrm{~g}$, casein: $0.3 \mathrm{~g}$, $\mathrm{MgSO}_{4} \cdot 7 \mathrm{H}_{2} \mathrm{O}: 0.05 \mathrm{~g}, \mathrm{CaCO}_{3}: 0.02 \mathrm{~g}, \mathrm{FeSO}_{4} \cdot 7 \mathrm{H}_{2} \mathrm{O}: 0.01 \mathrm{~g}$, Distilled water: 1litre, $\mathrm{pH}: 7.0$ ) by incubating on shaker at $35^{\circ} \mathrm{C}$ for 7 days. Effects of different incubation temperatures $(25,30,35,40$, $45,50,55$ and $\left.60^{\circ} \mathrm{C}\right)$ and initial $\mathrm{pH}(4,5,6,7,8$ and 9) of the medium on protease estimation just after $96 \mathrm{~h}$ were screened in broth. Effect of casein degradation on $\mathrm{pH}$ was also noticed on daily basis. Different carbon sources such as $1.0 \%$ glucose, sucrose, fructose, lactose, and mixture of glucose + sucrose, both at $0.5 \%$ were also tested. Nitrogen sources were $0.5 \%$ yeast extract, ammonium sulphate, sodium nitrate, urea and ammonium acetate. All the experiments were carried out in triplicate and averages were reproduced.

\section{Assay for protease enzyme}

The isolates, SK701 and SK709 with protease activities were allowed to grow starch casein broth medium at $35^{\circ} \mathrm{C}$ for 2 days on a rotary shaker at $150 \mathrm{rpm}$. Then $1 \mathrm{ml}$ of such grown bacterial suspension was again cultivated in starch casein broth medium $(40 \mathrm{~mL})$ in $250 \mathrm{~mL}$ Erlenmeyer flasks for 7 days at $37^{\circ} \mathrm{C}$ at $200 \mathrm{rpm}$. After due period, centrifugation of broth suspension was carried out at $10,000 \mathrm{rpm}$ for $15 \mathrm{~min}$ and cell free supernatant was separated for protease activity assay. The method of Tsuchida et al. [10] for protease estimation was followed. $250 \mathrm{ml}$ of starch casein broth was prepared and inoculated with SK701 and SK709 separately and incubated at $37^{\circ} \mathrm{C}$ for 7 days in incubator shaker at $180 \mathrm{rpm}$. After that the whole broth was centrifuged at $10000 \mathrm{rpm}$ at $4^{\circ} \mathrm{C}$ for $20 \mathrm{~min}$ and the clear supernatant was taken as crude enzyme and was stored at $4^{\circ} \mathrm{C}$. A mixture of $500 \mu \mathrm{l}$ of $1 \%(\mathrm{w} / \mathrm{v})$ of casein in $50 \mathrm{mM}$ phosphate buffer (pH 7) and $200 \mu$ l crude enzyme extract were incubated in a waterbath at $40^{\circ} \mathrm{C}$ for $20 \mathrm{~min}$. After that the enzyme reaction was terminated by adding $1 \mathrm{ml}$ of $10 \%(\mathrm{w} / \mathrm{v}$ ) TCA and was kept at room temperature for $15 \mathrm{~min}$. The reaction mixture was centrifuged to separate the unreacted casein at $10,000 \mathrm{rpm}$ for $5 \mathrm{~min}$. The supernatant was then mixed with $2.5 \mathrm{ml}$ of $0.4 \mathrm{M} \mathrm{Na}_{2} \mathrm{CO}_{3} .1 \mathrm{ml}$ of 3 -fold diluted Folin and Ciocalteus Phenol reagent was added. The resulting solution was incubated at room temperature in dark for $30 \mathrm{~min}$ and the absorbance of the blue colour, thus developed, was measured at $660 \mathrm{~nm}$ against a reagent blank using tyrosine.Since SK709 had shown maximum proteolytic activity and thus selected for further investigation. 


\section{Extraction of bioactive compounds}

$10 \mathrm{ml}$ of overnight culture of the isolate SK709 was transferred into conical flask containing $500 \mathrm{ml}$ of Bennet medium (sterilized with steam explosion) individually and incubated for 7 days at $24^{\circ} \mathrm{C}$ at $200 \mathrm{rpm}$ and $\mathrm{pH}(7.0 \pm 0.2)$. Further the mass cultured broth was filtered through cheese cloth to get clear filtrate. Further, equal volume (1:1) of ethanol was added \& mixed by vortexing \& kept without disturbance. The organic phase was collected \& evaporated at $70^{\circ} \mathrm{C}$ in an incubator. The obtained residue was stored at $-20^{\circ} \mathrm{C}$ for cytotoxicity assay.

\section{Cytotoxicity assay}

EAC (Ehrlich Ascites Carcinoma), SiHa (Human cervical cancer) and $\mathrm{HepG}_{2}$ (Hepatic carcinoma) cell lines were procured from NCCS Pune, India. Cells were cultured and maintained in Dulbecco's Modified Eagle's Medium (DMEM) with 10\% Fetal Bovine Serum and antibiotics in a humidified atmosphere of 5\% $\mathrm{CO}_{2}$ at $37^{\circ} \mathrm{C}$ in culture dishes/flasks. Stock culture was maintained in the exponential growth phase by passaging as monolayer culture using in $0.02 \%$ EDTA. The dislodged cells were suspended in complete medium and reseeded routinely.

The cytotoxic effects were assessed against EAC, SiHa and $\mathrm{HepG}_{2}$ cells at the varying concentrations of plant extracts by the MTT assay. The 3-(4,5-dimethyl-2-yl)-2,5-diphynyl tetrazolium bromide (MTT) is metabolic substrate which is reduced by the mitochondrial succinate dehydrogenase enzyme and forms formazan crystal. In brief cells were seeded overnight and then incubated with various concentration of extracts for $72 \mathrm{~h}$. At the end of the treatment, medium was removed, and cells were incubated with $20 \mu \mathrm{l}$ of MTT $(5 \mathrm{mg} / \mathrm{ml}$ in PBS) in fresh medium $(50 \mu \mathrm{l})$ for $4 \mathrm{hrs}$ in $\mathrm{CO}_{2}$ incubator. After the treatment formazan crystal, formed by mitochondrial reduction of MTT were solubilised in DMSO (150 $\mu \mathrm{l} /$ well) and the absorbance was read at $570 \mathrm{~nm}$ after $10 \mathrm{~min}$ incubation on the iMark Microplate Reader (Bio-Rad, USA). Percent cytotoxicity $\left(\mathrm{IC}_{50}\right)$ values were determined by extrapolating the graph.

\section{Molecular characterization}

\section{Genomic DNA extraction}

Genomic DNA of SK709 was isolated using standard protocol [11] and purity of DNAwas checked A280/A260. Further bands were visualized by running on $(0.8 \% \mathrm{w} / \mathrm{v})$ agarose gel electrophoresis.

\section{S rRNA gene amplification and sequencing}

16S rRNA gene of isolated genomic DNA of SK709 was amplified [12] in a PCR thermal cycler (Genetix) by universal primers, 9F (5'GAGTTTGATCCTGGCTCAG3') \& 1541R (5'AAGGAGGTGATCCAACC3'). The reaction mixture contained $2 \mu \mathrm{g}$ of dNTPs mixture ( $1.25 \mathrm{mM}$ each), $1 \mu \mathrm{g}$ of each of the primers, $2.5 \mu \mathrm{g}$ of DNA, $1 \mu \mathrm{l}$ of Taq polymerase and sterile deionised water to make final volume $100 \mu \mathrm{l}$. PCR consists of an initial denaturation at $94^{\circ} \mathrm{C}$ for $1 \mathrm{~min}$, annealing at $63^{\circ} \mathrm{C}$ for $1 \mathrm{~min}$ and $72^{\circ} \mathrm{C}$ for $1 \mathrm{~min}$ \& final $5 \mathrm{~min}$ extension at $72^{\circ} \mathrm{C}$. The PCR amplified product were stained with ethydium bromide and run on agarose $(1.2 \%)$ gel electrophoresis and examined under gel documentation system. The complete 16S rRNA gene of SK709 was sequenced by using PCR products at Samved Biotech, Ahmedabad.

\section{Construction of phylogenetic tree}

The 16S rRNA gene sequence of SK709 were compared with other bacterial sequences by using NCBI BLAST programme. Multiple sequence alignment \& phylogenetic tree were constructed using software programme MEGA 4.0 [13]. The 16S rRNA sequence of strain SK709 was submitted to GenBank (Nucleotide database of NCBI). The sequence was accepted and the accession number (KF849411) for SK709 was obtained.

\section{Results}

\section{Isolation \& Identification of protease producing microbes}

Table 1: Cultural and morphological characteristics of the bacterial isolates on Skimmed milk agar medium.

\begin{tabular}{|c|c|c|c|c|c|}
\hline Bacterial Isolate & Source of Isolation & Colony Colour & Spore Morphology & Presence of Halo zone & Diffusible Pigments \\
\hline SK701 (SK11L) & Litchi, Muz. & White-grey & Smooth oval & $+(4 \mathrm{~mm})$ & Nil \\
\hline SK709 (SK34L) & Litchi, Muz. & White-red & Oval red & $+++(28 \mathrm{~mm})$ & Orange-red \\
\hline
\end{tabular}

Bacterial strains, isolated from the rhizosphere of Muzaffarpur were grown on starch agar medium, supplemented with nystatin and were screened colony colour, spore morphology, $[14,15]$ mycelia colour, etc. (Table 1). Two bacterial strains, SK701 and Sk709 of litchi orchard of Muzaffarpur were confirmed with proteolytic activities as they developed halo regions on Skimmed milk agar plates.But isolate SK709 was more prominent having approximately $28 \mathrm{~mm}$ clear halo zones around colonies or streaked mycelia on fourth day of incubation (Figure 1). Purified strains were examined under microscope for gram staining and Isolate SK709 was found to be gram negative whereas isolate SK701 with many others were found to be gram positive. Further both isolated reacted positively in different biochemical and physiological tests (Table 2). Sucrose was found to be the optimum source among carbon compounds and beef extract for protease production. The optimum growth of bacterial isolates was found at $\mathrm{pH} 7.8$ and temperature at $35 \pm 2^{\circ} \mathrm{C}$. 

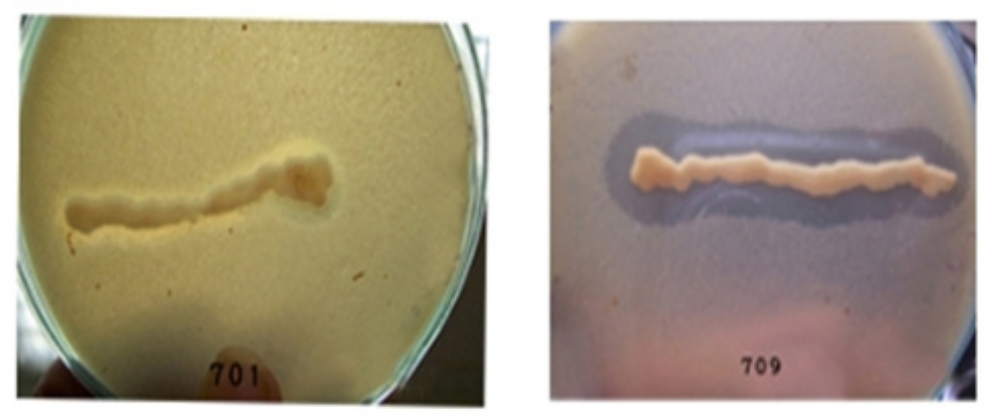

Figure 1: Formation of halo regions around streaked mycelia of Isolate SK701and SK709 on skimmed milk agar medium after 4-5 days.

Table 2: Physiological and biochemical characteristics of bacterial isolates SK701 and SK709.

\begin{tabular}{|c|c|c|c|c|c|}
\hline \multirow{2}{*}{ Character } & \multicolumn{2}{|c|}{ Results } & \multirow{2}{*}{ Character } & \multicolumn{2}{|c|}{ Results } \\
\hline & 701 & 709 & & 701 & 709 \\
\hline Gram staining & $+\mathrm{ve}$ & -ve & Tolerance to $\mathrm{NaCl} \%$ & $2-5$ & $2-4$ \\
\hline Enzyme activities: & pH range & $5-7$ & $2-4$ & & \\
\hline Indole production & -ve & -ve & $\operatorname{Temp}\left( \pm 2^{\circ} \mathrm{C}\right)$ & 35 & 35 \\
\hline Methyl red & -ve & -ve & \multicolumn{3}{|c|}{ Carbon \& Nitrogen source } \\
\hline Voges Proskauer & -ve & -ve & Glucose (1\%) & +ve & $+\mathrm{ve}$ \\
\hline Citrate utilization & $+\mathrm{ve}$ & $+\mathrm{ve}$ & Sucrose $(1 \%)$ & $+\mathrm{ve}$ & $+\mathrm{ve}$ \\
\hline Casein hydrolysis & $+\mathrm{ve}$ & $+\mathrm{ve}$ & Fructose $(1 \%)$ & $+\mathrm{ve}$ & $+\mathrm{ve}$ \\
\hline Urea hydrolysis & +ve & $+\mathrm{ve}$ & Lactose $(1 \%)$ & -ve & -ve \\
\hline Starch hydrolysis & -ve & -ve & $\begin{array}{c}\text { Glucose }+ \text { Sucrose } \\
(0.5 \%)\end{array}$ & $+\mathrm{ve}$ & $+\mathrm{ve}$ \\
\hline Gelatin hydrolysis & -ve & $+\mathrm{ve}$ & Glycine & $+\mathrm{ve}$ & $+\mathrm{ve}$ \\
\hline $\mathrm{H}_{2} \mathrm{~S}$ production & -ve & -ve & Malt extract & $+\mathrm{ve}$ & $+\mathrm{ve}$ \\
\hline
\end{tabular}

\section{Proteolytic activities}

Growth of the bacteria and protease production were found to be maximum on $4^{\text {th }}$ day of incubation. The casein-degradation activities by releasing proteinase was found maximum $(64.6 \mathrm{U} /$ $\mathrm{ml}$ ) on $4^{\text {th }}$ day (Figure 2).The $\mathrm{pH}$ above 7.0 was required in case of gram negative isolate SK709 whereas $\mathrm{pH}$ with less than 7.0 favoured the growth of other bacterial strains including SK 701. The $\mathrm{pH}$ of the broth started to increase with the growth of isolate SK709, the value reached to 7.8 on $4^{\text {th }}$ day after $96 \mathrm{~h}$ of incubation (Figure 3). The effective temperature for maximum protease activities was noticed at $35 \pm 2^{\circ} \mathrm{C}$. At high temperature $\left(>45^{\circ} \mathrm{C}\right)$, the protease activities dropped to the level of $20 \%$ (Figure 4).

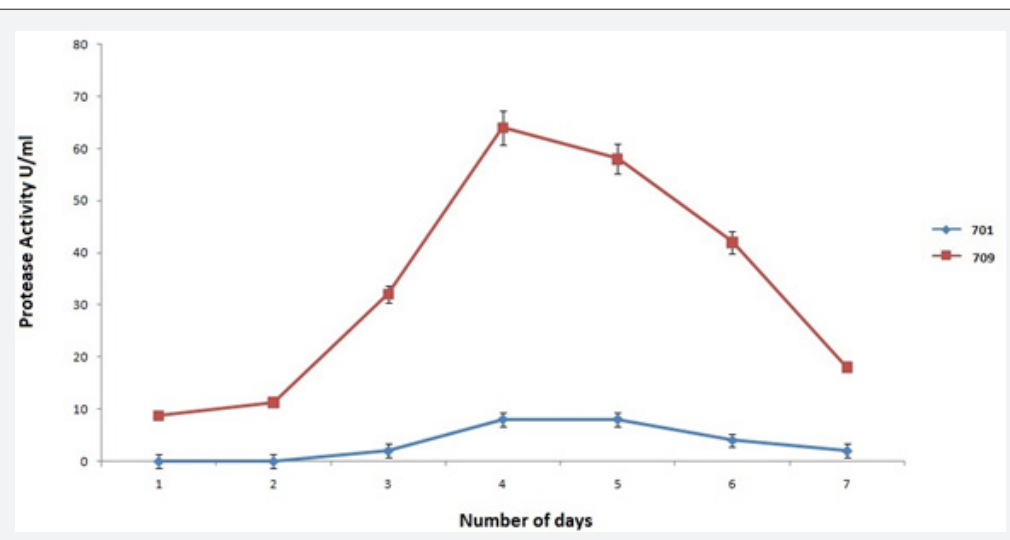

Figure 2: Quantitative estimation of protease activities of bacterial isolates SK701and SK709 in Starchcasein broth. 


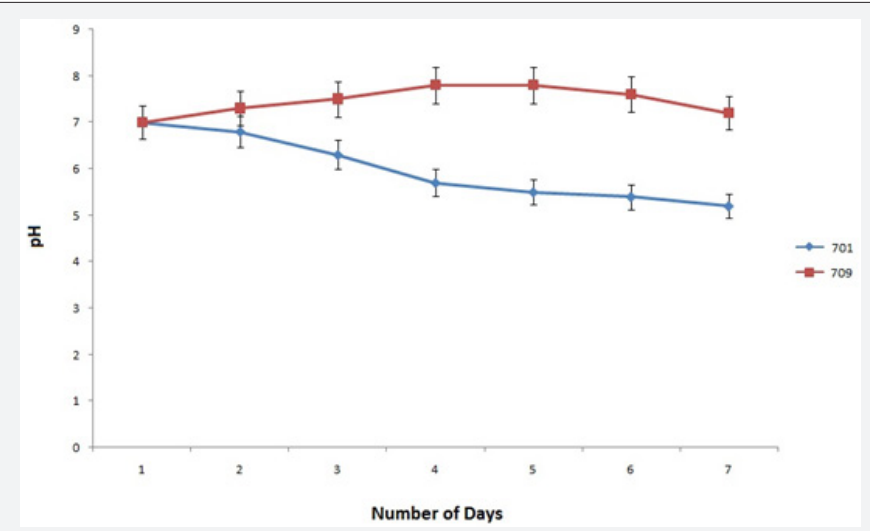

Figure 3: Change in pH during growth of bacterial isolates SK701 and SK709from day 1 to 7.

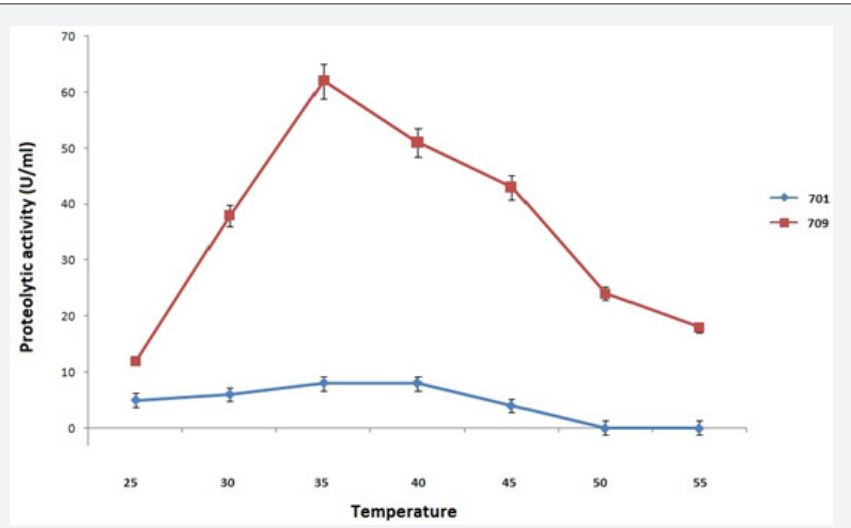

Figure 4: Effect of temperature on protease activities in bacterial isolates SK701and SK709.

\section{Cytotoxicity}

The cytotoxicity effect of crude extract of isolate SK709 was assayed against EAC, $\mathrm{SiHa}$ and $\mathrm{HepG}_{2}$ cells at the varying concentration by MTT assay. The data of MTT assay were used to extrapolate $\mathrm{IC}_{50}$ of the extracts of these cell lines, which was found dose $(200 \mu \mathrm{g} / \mathrm{ml})$ and time dependent $(72 \mathrm{~h})$. Among the three cancer cell lines (Figure 5), EAC showed the minimum concentration $\mathrm{IC}_{50}$ value $(17.2 \mu \mathrm{g} / \mathrm{ml})$ followed by SiHa $(26.5 \mu \mathrm{g} /$ $\mathrm{ml}$ ) and $\mathrm{Hep}_{2}(35.5 \mu \mathrm{g} / \mathrm{ml})$.

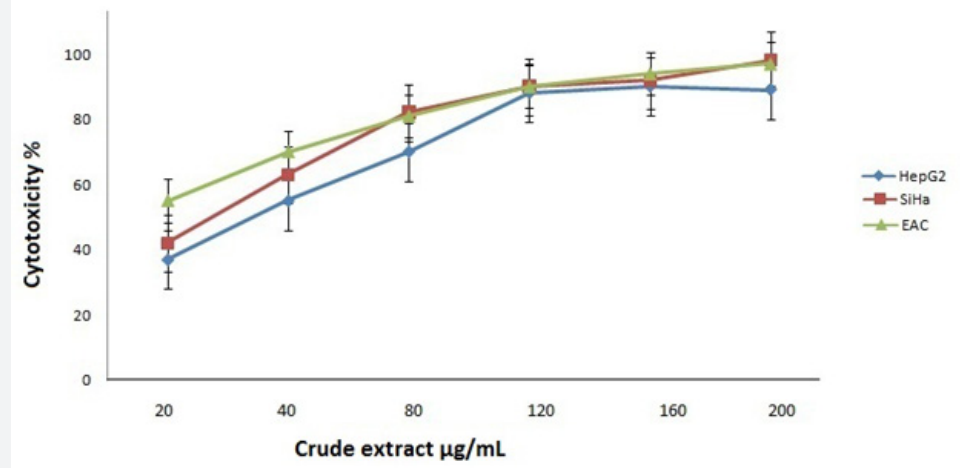

Figure 5: Percentage cytotoxicity of different concentrations of cell free extractsof bacterial isolates SK701and SK709 against EAC, SiHa and HepG2cell lines.

\section{DNA Amplification}

The genomic DNA of the proteolytic isolate SK709 was isolated by standard protocol [16] and the samples were run on
$0.8 \%$ agarose gel electrophoresis. Thereafter PCR amplification using universal primers resulted into a single discrete amplicon band of $1.5 \mathrm{~kb}$ of $16 \mathrm{~S}$ rRNA gene (Figure 6). 


\section{International Journal of Cell Science \& Molecular Biology}

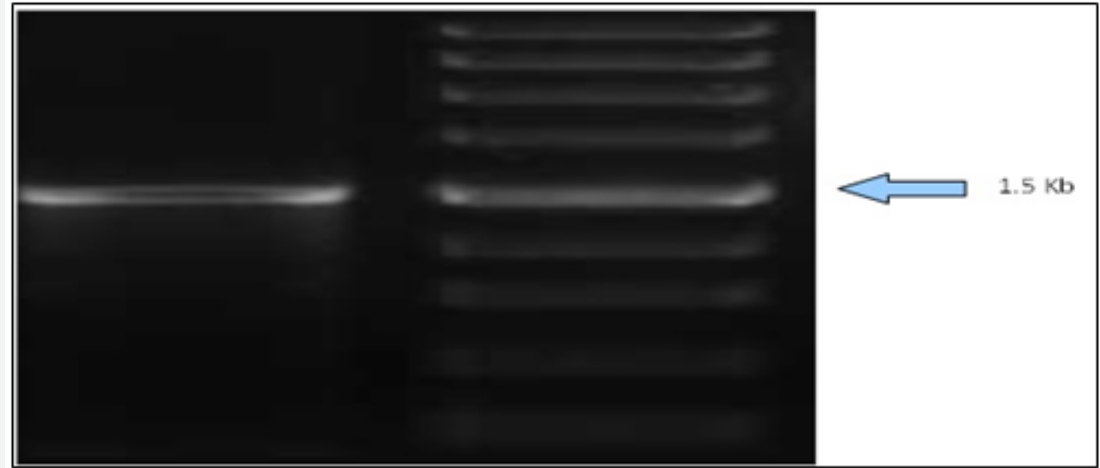

(a) (b)

Figure 6: PCR amplified product of 16S rRNA gene of $1.5 \mathrm{~kb}$ of bacteriallsolate SK709 (a) on agarose gel electrophoresis: Control (b)

\section{Molecular characterization of the selected isolate}

The NCBI BLAST homology analysis of 16S rRNA gene of SK709 showed maximum similarity ( $\geq 98 \%$ ) with Stenotrophomonas sp. Based on the result, phylogenetic tree was constructed using neighour joining method (Figure 7).Thesequence (Table3) was published after trimming and assembling to NCBI(http//: www. ncbi.nlm.nih.gov). It was revealed that the strain SK709 showed 1001 base similarity out of 1022 (98\%) with Stenotrophomonas sp. MCYF1(NCBI Accession no. KC734883.1). Thus, the difference of 21 nucleotides in the 16S rRNA gene qualified the strain SK 709 to earn a separate NCBI Accession no. KF484911.

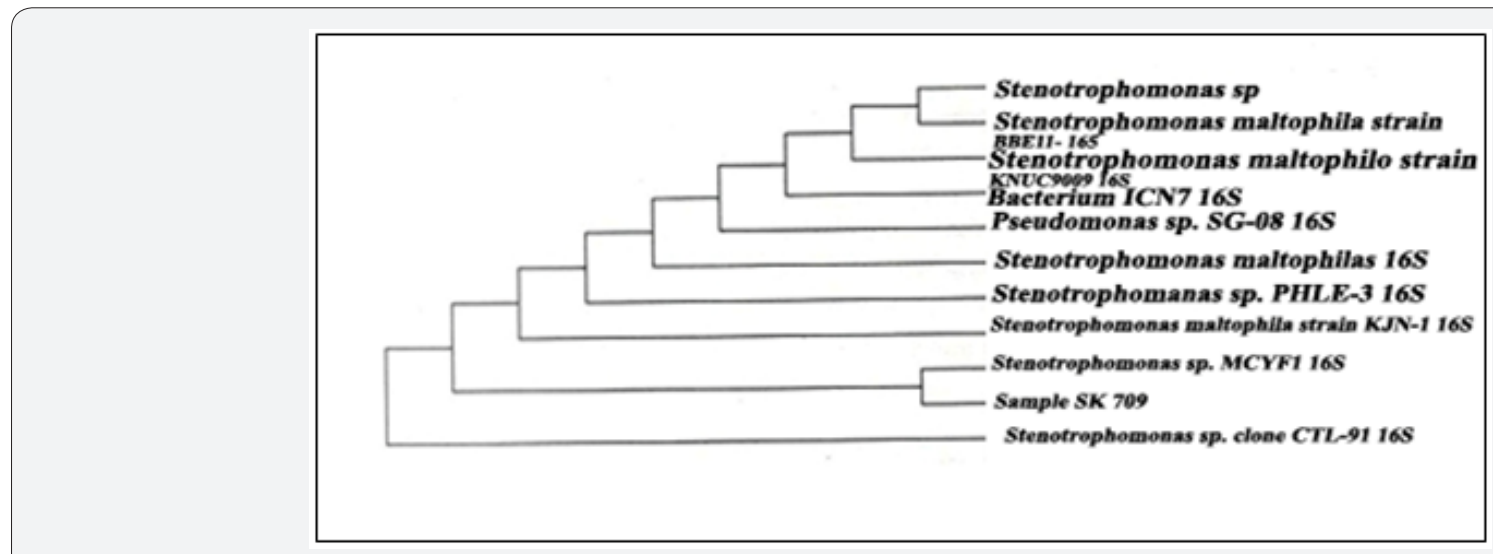

Figure 7: Phylogenetic tree based on 16S rRNA gene sequence showingrelationship between Isolate SK709 (Stenotrophomonas sp. Strain SK34 $)$ and ten related members.

Table 3: The 16S rRNA gene sequencing of bacterial isolate SK709 Strain SK34L (1022bp).

\begin{tabular}{|l|}
\hline tattatcagcacaggagagcttgctctctgggtggcgagtggc ggacgggtgaggaatac atcggaatctactctgtcgt \\
gggggataac gtagggaaac ttacgctaat accgcatacgacctacgggt gaaagcaggg gaccttcggg cctt \\
gcgcga ttgaatgagccgatgtcggattagctagttggc ggggtaaaggcccaccaaggcgac gatccgtagctggt \\
ctgagaggatgatcagccacactggaactgagacacggtccagactcctacgggaggcagcagtggggaatattgga \\
caatgggcgcaagcctgatccagccataccgcgtgggtgaagaaggccttcgggttgtaaagcccttttgttgggaaag \\
aaatccagctggctaatacccggttgggatgacggtacccaaagaataagcaccggctaacttcgtgccagcagccgc \\
ggtaa tacgaagggtgcaagcgtta ctcggaatta ctgggcgtaa agcgtgcgta ggtggtcgtttaagtccgttgt \\
gaaagccc tgggctcaac ctgggaactgcagtggatac tgggcgacta gaatgtggtagagggtagcg gaattc \\
ctggtgtagcagtgaaatgcgtagagatcaggaggaacatccatggc gaaggcagctacctggaccaacattga \\
cactgaggca cgaaagcgtg gggagcaaacaggattagat accctggtag tccacgccct aaacgatgcgaact \\
ggatgt tgggtgcaatttggcacgcagtatcgaagctaacgcgttaagttcgccgcctggggagtacggtcgcaag \\
actgaaactc aaaggaattgacgggggcccgcacaagcggtggagtatgtggtttaattcatgc aacgc gagaacctt \\
acctggccttgacatgtcgagaactttccagagatggattggtgccttcgggaactcgaacacaggtgctgcatggctgt \\
cgtcagctcgtgtcgtgagacg
\end{tabular}




\section{Discussion}

Microorganisms are usefulness in food and dairy industries, pharmaceutical sectors, leather industries etc. They produce a variety of bioactive substances and secondary metabolites. Nowa-days, they are an important producers of industrial significant enzymes viz. protease, amylase, phytase, cellulase, lipase, etc. $[17,18]$. Proteases are one of such novel enzyme that is useful in day-to-day activities. Most of the bacterial strains were isolated on starch agar medium. In order to obtain a specific byproduct, the medium requires some modifications. Thus, a specific protease screening medium (skim milk agar medium) was used for screening casein degrading isolates. Cultural, morphological, physiological, biochemical properties revealed the strains SK701 \& SK709, isolated from rhizosphere of litchi orchard of Muzaffarpur to be the species of genera Streptomyces (actinomycetes group) and Stenotrophomonas (Pseudomanad group), respectively. The generic status of these strains SK701 and SK709 was not only confirmed by physiological and cultural characterization but also by the Burgey's manual of Determinative Bacteriology $[16,17]$. However, the final support of the recognition Stenotrophomonas was established on the basis of phylogenetic tree constructed using $16 \mathrm{~S}$ rRNA gene sequencing [19,20].

The proteolytic activity in broth was observed after $96 \mathrm{~h}$ of incubation during the stationary phase. The protease activity was optimum at $35^{\circ}$ Cand showing maximum activity $\mathrm{pH} 7.8$, confirming alkaline nature of protease enzyme [21]. Different alkaline protease producing alkalophilic strains have been reported [5].Alkaline proteases showed better resistance to alkali and other denaturing chemicals in the reaction mixture \& have higher affinity towards proteinaceous substrates thus it could be proved as a very good detergent supplement. The organism showed optimum growth near $35 \pm 2{ }^{\circ} \mathrm{C}$ indicating its mesophilic nature. In present investigation optimum protease production was obtained by combination of sucrose (carbon source) \& beef extract (nitrogen source).

In present study an attempt was made to find cytotoxic activity from the extract of Stenotrophomonas sp. Earlier Figueiredo et al. [9] have reported cytotoxic activity in Stenotrophomonas maltophila. The bacterial isolate showed $\mathrm{IC}_{50}$ value $17.2 \mu \mathrm{g} / \mathrm{ml}$, $26.5 \mu \mathrm{g} / \mathrm{ml}$ and $35.5 \mu \mathrm{g} / \mathrm{ml}$ in EAC, SiHa and Hep $\mathrm{G}_{2}$ cancer cell lines, respectively. Suffness et al.[22], have reported that the $\mathrm{IC}_{50}$ values less than $30 \mu \mathrm{g} / \mathrm{ml}$ in cancer cell lines can be considered as potent for anticancer drug development[23]. This report augurs that the extract of SK 709 may prove a beneficial chemical to fight against cancer and the protease may have the ability to make alteration in protein configuration in cancer cell lines leading to apoptosis and thus hindering the growth of tumour cells.

\section{Conclusion}

The isolate SK709 with proteolytic activity on skimmed milk agar medium was identified as Stenotrophomonas on the basis of morphological, cultural, biochemical and physiological characteristics as well as $16 \mathrm{~S}$ rRNA gene sequencing. On the basis of $98 \%$ blast homology data base similarity with Stenotrophomonas sp.MCYF1(KC734883.1), the isolate SK709 was christened as Stenotrophomonas sp strain SK $34^{\mathrm{L}}$ and because of the difference of 21 nucleotides which amounts to $2 \%$, the strain earned a fresh accession no. KF849411.

\section{Conflict of interest statement}

The authors have no conflict of interest associated with this study.

\section{Acknowledgements}

Authors are thankful to the Head of the Department of Botany for providing proper facilities to work. SKas Project Fellows and US as as P I, DST WOS-A,are thankful to the University Grants Commission, New Delhi for granting financial support under UGC SAP (DRS-Phase 1) scheme to the University Department of Botany, B R A Bihar University Muzaffarpur (File No. F.3-13/2009SAP-II) and to the Department of Science and Technology, New Delhi (File No. SR/WOS-A/LS-289/2011), respectively.

\section{References}

1. Sethi S, Kumar R, Gupta S (2013) Antibiotic production by microbes isolated from Soil.International Journal of Pharmaceutical Sciences and Research 4: 2967-2973.

2. Cherry JR, Fidants AL (2003) Directed evolution of industrial enzymes: an update. Curr Opin Biotechnol 14: 438-443.

3. Jeyadharshan VN (2013) Production \& partial purification of protease by actinomycetes species. International Journal of Scientific \& Research Publications 3(4):1-3.

4. Jain R, Agrawal SC, Jain PC (2008-2009) Proteolytic actinomycetes from Indian habitats. Journal of Culture Collection 6:28-37.

5. Mehta VJ, Thumar JT, SinghSP (2006) Production of alkaline protease from an alkalophilic actinomycete. Bioresource Technology 97:16501654.

6. Guravaiah M, Daniel K, Prabhakar T, Hatti I, Sirisha P(2012) Screening, isolation, characterization and strain improvement of Streptomyces indicus GAS-4. Indian Journal of Science 1:77-83.

7. Mathew CD, Gunathilaka (2015) Production, purification and characterization of a thermostable alkaline serine protease fromBacillus lichniformisNMS-1. International Journal for Biotechnology and Molecular Biology 6: 19-27.

8. Edberg SC, Gallo P, Kontnick C (1996) Analysis of the virulence characterstics of bacteria isolated from bottled water cooler and tap water. Microbial Ecology in Health and Diseases 9:67-77.

9. Figueiredo PMS, Furumura MT, Santo AM, Sousa ACT, Kota DJ(2006) Cytotoxic activity of clinical Stenotrophomonas maltophila. Applied Microbiology 43:443-449.

10. Tsuchida O, Yamagata Y, Ishizuka J (1986) An Alkaline proteinase an alkalophilic Bacillus sp. Current Microbiology 14:7-12.

11. Wang TY, Wang L, Zhang JH, Dong WH (2011) A simplified universal genomic DNA extraction protocol suitable for PCR. Genetics Molecular Research10:519-525.

12. Olmezoglu E, Herand BK, Oncel MS, Tune K, Ozkan M (2012) Copper bioremoval by novel bacterial isolates and their identification by $16 \mathrm{~S}$ rRNA gene sequence analysis. Turkish Journal of Biology36:469-476. 
13. Tamura K, Dudley J, Nei M, Kumar S (2007) MEGA 4 molecular evolutionary genetics analysis (MEGA) software version 4.0. Molecular Biology Evolution 24(8): 1596-1599.

14. Phridham TG, Tresner HD (1974) Genus I Streptomyces. In: Waksman \& Henrici, Buchnan RE, Gibbons NE (Eds.), Bergey's Manual of determinative bacteriology ( $8^{\text {th }}$ edn), Williams \& Wilkins, Baltimore, UABaltimore, USA,pp. 748-829.

15. Holt JG, Krieg HR, Sneath PHA, Staley JT, WilliamsST(1994) Bergey's manual of determinative bacteriology, $\left(9^{\text {th }}\right.$ edn). Lippincott Williams \& Wilkins, Baltimore, USA.

16. Kieser T, Bibb MJ, Buttner MJ, Chater KF, Hopwood DA (2000) Practical StreptomycesGenetics. The John Innes Foundation, Norwich, England.

17. Sharma U, Kumari S, Sinha K, Kumar S (2017) Isolation and molecular characterization of phytase producing actinobacteria of fruit orchard. The Nucleus 60:187-195.

18. Kumari S, Sharma U, Krishna R, Sinha K, Kumar S (2018) Screening and molecular characterization of cellulase producing actinobacteria from Litchi Orchard. Current Chemical Biology 12(2).

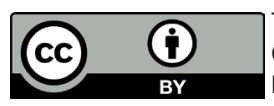

This work is licensed under Creative Commons Attribution 4.0 License

DOI: 10.19080/IJCSMB.2018.05.555660
19. Saitou N, Nei M (1987) The neighbor-joining method: a new method for constructing phylogenetic trees. Mol Biol Evol 4: 406-425.

20. Kimura M (1980) A simple method for estimating evolutionary rates of base substitutions through comparative studies of nucleotide sequences J Mol Evol 16:111-120.

21.Viswanathan K,Rebecca LJ,Arumugan P (2017) Optimization of protease enzyme production by marine actinomycetes. International Journal of Pharmacy and Biological Sciences 8: 188-194.

22. Suffness M, Pezzuto JM (2009) Assay related to cancer drug discovery, In:Hostettemank (Edt.), Methods in plant biochemistry: assay for bioactivity. Academic Press, London, England, pp. 71-133.

23. Ravikumar S, Fredimoses M, Gnandesigan M (2012) Anticancer property of sediment actinomycetes against MCF-7 \& MDA-MB-231 cell lines. Asian Pac Jof Trop Biomed 2: 92-96.

\section{Your next submission with Juniper Publishers will reach you the below assets}

- Quality Editorial service

- Swift Peer Review

- Reprints availability

- E-prints Service

- Manuscript Podcast for convenient understanding

- Global attainment for your research

- Manuscript accessibility in different formats

( Pdf, E-pub, Full Text, Audio)

- Unceasing customer service

Track the below URL for one-step submission https://juniperpublishers.com/online-submission.php 